EESTI NSV TEADUSTE AKADEEMIA TOIMETISED. 28. KOIDE KEEMIA. 1979, NR. 2

ИЗВЕСТИЯ АКАДЕМИИ НАУК ЭСТОНСКОЙ ССР. ТОМ 28 ХИМИЯ. 1979, № 2

\title{
ОБ АЛКИЛИРОВАНИИ АМИНОВ ЛАВАНДУЛИЛХЛОРИДОМ
}

T. KAAL, Lilja LAHE, K. LAATS. AMIINIDE ALKOLEERIMISEST LAVANDULOOLKLORIIDIGA

T. KAAL, Lilya LAHE, $K$. LAATS. ON ALKYLATION OF AMINES WITH LAVANDULYL CHLORIDE

Лавандулилхлорид (2,6-диметил-3-хлорметил-1,5-гептадиен) - один из компонентов смеси терпеновых хлоридов, образующихся при теломеризации изопрена с его гидрохлоридами $\left[{ }^{1}\right]$. В отличие от остальных изомерных хлоридов, он не вступает в реакцию омыления. Соответствующий спирт - ценное душистое вещество - может быть получен косвенным путем через магнийорганическое соединение $\left[{ }^{2}\right]$. Представляет интерес выяснение способности этого хлорида вступать в другие реакции нуклеофильного замещения. В настоящей работе изложены результаты изучения реакции лавандулилхлорида с некоторыми аминами.

Одним из аминов, сравнительно легко алкилируемых алкилгалогенидами, является моноэтаноламин. Реакция обычно проводится в кипящем этиловом или изопропиловом спирте $\left[{ }^{3,4}\right]$. Нами для реакции с этаноламином был применен продукт омыления терпеновых хлоридов, содержащий лавандулилхлорид и терпеновые спирты. Последние играют роль растворителя, что позволяет также повысить температуру реакции (хлорпроизводные в обычных условиях мало реакционноспособны).

Этаноламин алкилируется уже при кипячении в течение 1 ч с обратным холодильником (при $\approx 170^{\circ} \mathrm{C}$ ). Сравнительно легко реагировал также бензиламин - реакция завершалась за 4 ч. С морфолином за 6 ч прореагировало около $40 \%$ амина. Анилин в реакцию не вступал. По-видимому, $\mathrm{pK}_{в}$ амина должен иметь величину не менее 5-6 (у этаноламина, бензиламина и морфолина она, соответственно, 4,6; 4,7; 5,6). Гидрохлорид образовавшегося алкилированного амина при действии избытка исходного амина переходит в соль последнего; таким образом в реакции с бензиламином выделены лавандулилбензиламин и гидрохлорид бензиламина.

На основе алкилирования моноэтаноламина лавандулилхлоридом разработан метод выделения терпеновых спиртов из смеси с соответствующими хлоридами $\left[{ }^{5}\right]$.

\section{Экспериментальная часть}

К продукту омыления терпеновых хлоридов (\%: терпеновых спиртов 65, лавандулилхлорида 20 и терпеновых углеводородов 15) добавляли 5-кратный избыток соответствующего амина (в расчете на лавандулилхлорид) и кипятили реакционную смесь с обратным холодильником в течение $1-4$ ч. Кристаллы гидрохлорида амина отделяли фильтрованием и жидкий продукт разбавляли водой. Отделяли верхний слой, который 


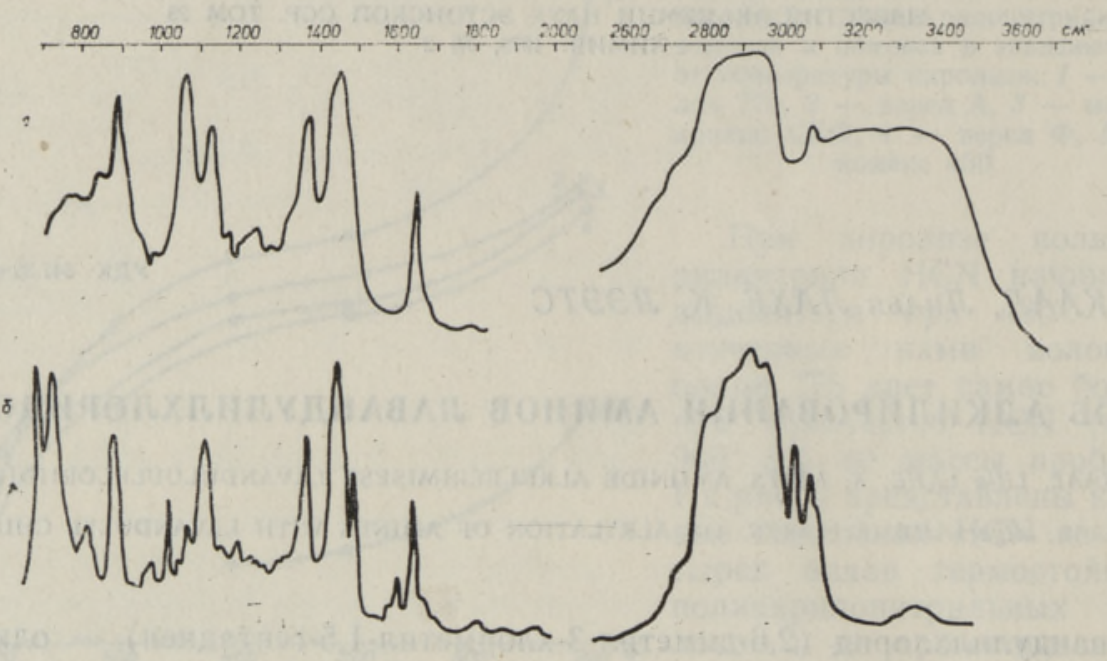

ИК-спектры лавандулнлэтаноламина (a) и лавандулилбензиламина (б).

после дополнительной промывки водой был высушен на поташе. Продукт реакции разгоняли в вакууме. Выход алкилированных аминов - $80-85 \%$ от теоретического.

Лавандулилэтаноламин: т. кип. $122-125 / 2 ; d_{4}{ }^{20} 0,9273 ; n_{D}{ }^{20} 1,4860$. Найдено, \%: С 73,2 ; Н 11,9; N 7,0. Вычислено, \%: С 73,05; Н 11,75; N 7,10. Лавандулилбензиламин: т. кип. $135-138 / 2 ; d_{4}{ }^{20} 0,9361 ; n_{D}{ }^{20} 1,5178$. Найдено, $\%$ : С 84,$1 ; \mathrm{H} 10,3 ; \mathrm{N} 5,6$. Вычислено, \%: С 83,89; Н 10,35; N 5,76. Вычислено для гидрохлорида бензиламина, \%: С 58,56 ; Н 7,02; N 9,76. Найдено, \%: С 58,9 ; Н 7,2; N 9,5. В случае этаноламина гидрохлорид не выделен.

ИК-спектры полученных аминов приведены на рисунке.

В спектре лавандулилэтаноламина $(a)$ отдельные структурные элементы характеризуются следующими максимумами поглощения: $\mathrm{CR}^{1} \mathrm{R}^{2}=\mathrm{CH}_{2} 890,1645 ; \mathrm{OH} 1060$ и 3300-3430 (ассоциат); NH $3315 \mathrm{~cm}^{-1}$ (ассоциат). В спектре лавандулилбензиламина (б) двойной связи $\mathrm{CR}^{1} \mathrm{R}^{2}=\mathrm{CHR}^{3}$ соответствует максимум поглощения при 825 ; $\mathrm{CR}^{1} \mathrm{R}^{2}=\mathrm{CH}_{2} 890$ и 1645 ; бензольному кольцу $700,740,1030,1075,1495,1605,1800$, 1870 и 1945; NH $3330 \mathrm{~cm}^{-1}$ (ассоциат). Спектры сняты на приборе UR-10 в тонком слое.

\section{Л ИТЕРАТУРА}

1. Лээтс К. В., Каал Т. А., Калья И. А., Кудрявцев И. Б., Мукс Э. А., Т а ли М. А., Т ен г С. Э., Э р м А. Ю. Определение изомерного состава фракции $\mathrm{C}_{10}$ теломера изопрена с его изомерными гидрохлоридами. - ЖОрХ, 1974 , т. 10 , вып. 2 , с. $159-\mathrm{l} 61$.

2. К а а л Т., Л э э Т с К. Получение лавандулола из димера гидрохлорида изопрена. Изв. АН ЭССР. Хим. Геол., 1973, т. 22, № 2, с. $180-182$.

3. Goldberg, S. D. Local anesthetic base and solution and their manufacture. Пат. США № 2139818, 1938.

4. Rie s e n berg, J. R. Esters of $\beta$-alkylaminoethanols. - J. Amer. Chem. Soc., 1945, N 6, p. 933-939.

5. Л ээ тс К. В., К а а л Т. А. Способ выделения терпеновых спиртов. Авт. свид. СССР № 497278, 1975, - Бюл. изобретений, 1975, № 48.

Ннститут химии

Академии наук Эстонской ССР
Поступила в редакцию 12/VI 1978 